\title{
Exchange New Product News
}

Journal of Derivatives \& Hedge Funds (2007) 13, 177-180. doi:10.1057/palgrave.jdhf.1850071

\section{PER CENT RISE IN TURNOVER ON XETRA IN MAY: TOTAL VOLUME OF $€ 233$ BILLION TRADED ON ALL STOCK EXCHANGES IN GERMANY}

In May $€ 212.7$ billion were turned over on Xetra and on the floor of Börse Frankfurt - a rise of 10 per cent year-on-year (May 2006: $€ 193$ billion). Thereof $€ 198.5$ billion were traded on Xetra gaining 11 per cent yearon-year (May 2006: €178.5 billion) and $€ 14.2$ billion on the floor. German equities accounted for $€ 200$ billion, foreign equities comprising $€ 12$ billion. More than 97 per cent of the transaction volume with German equities was executed at Börse Frankfurt. Almost 79.2 per cent of foreign equities were traded on Xetra and on the floor.

In the entire month 13.5 million transactions were executed on Xetra, a rise of 17 per cent year-on-year (May 2006: 11.5 million).

DaimlerChrysler AG was the strongest DAX $\mathbb{R}$ stock on Xetra in May at $€ 16.7$ billion. Merck KGAA was the top MDAX $($ stock at $€ 1.4$ billion while Air Berlin led the SDAX $\AA$ stock at $€ 287.6$ million and Solarworld AG headed the TecDAX $\AA$ at $€ 908$ million. At $€ 3.6$ billion, the DAX EX was once again the exchange-traded fund with the largest turnover.

On all stock exchanges in Germany $€ 233.8$ billion were traded in May according to orderbook turnover statistics - a rise of 9.8 per cent compared year-on-year (May 2006: €212.9 billion). This total included $€ 225.6$ billion in equities, warrants and exchange-traded funds, as well as $€ 8.1$ billion in fixed-income securities.

\section{EUREX WILL START WITH THREE CREDIT INDEX FUTURES: LAUNCH OF THE WORLD'S FIRST EXCHANGE- LISTED CREDIT INDEX FUTURES ON 27 MARCH}

Eurex, the international derivatives exchange, began trading in credit index futures on 27 March with three contracts. In addition to the already announced future based on the $i \operatorname{Traxx} \AA$ Europe five year, Eurex will offer futures contracts on the $i \operatorname{Traxx}(\mathrm{R}) \mathrm{HiVol}$ five year and $i \operatorname{Traxx} \mathbb{R}$ Crossover five-year indices. The iTraxx (B) Europe index is an equally weighted portfolio of the 125 most liquid European investment grade credit default swap (CDS) entities. The $i \operatorname{Traxx} \mathbb{R} \mathrm{HiVol}$ index is an equally weighted portfolio of the 30 entities with the highest spread from the $i \operatorname{Traxx}(\mathbb{R})$ Europe index. The $i \operatorname{Traxx} \AA$ Crossover index is an equally weighted portfolio of 45 European subinvestment grade entities.

All three underlying indices are provided by International Index Company Ltd. (IIC). The contracts will have fixed coupon and semiannual maturity dates in March and September. The Eurex $i \operatorname{Traxx} \AA$ credit futures will closely mimic the risk structure of CDSs traded in the 
over-the-counter (OTC) market. Trading on Eurex will involve Eurex Clearing as central counterparty, thereby reducing the counterparty and systemic risk and adding to the benefits the product will offer to users.

\section{BAHRAINI DINAR ELIGIBLE FOR SETTLEMENT IN CLEARSTREAM: SIX NEW DENOMINATION CURRENCIES ACCEPTED}

Clearstream has become the first International Central Security Depositary (ICSD) to accept the Bahraini Dinar (BHD) as eligible for settlement as of Monday, 28 May. Additionally six new currencies, the Qatari Rial, the Guatemalan Quetzal, the Dominican Peso, the Vietnamese Dong, the Sri Lanka Rupee and the Mongolian Tugrik have been accepted by Clearstream as denomination currencies.

This innovative move comes in response to growing demand by investment banks and issuers to issue and settle eurobonds denominated in BHD. The Bahraini Dinar is not a Bridge eligible currency. The Bridge is an electronic communications link that facilitates the efficient settlement of securities transactions between counterparties in Clearstream Banking Luxembourg and Euroclear Bank.

The six new currencies admitted by Clearstream will be denomination currencies, that is, only for the denomination of a bond issue. They will not be settlement currency, meaning that Clearstream's customers can issue securities in these currencies but they cannot settle against them. There are 41 currencies eligible for settlement in Clearstream and 51 denomination currencies.

\section{DEUTSCHE BÖRSE TO ISSUE BONUS SHARES AFTER CLOSE OF TRADING ON}

8TH JUNE, 2007: SHAREHOLDERS TO RECEIVE ONE BONUS SHARE PER SHARE/NEW SHARES TO CARRY FULL DIVIDEND RIGHTS FOR FISCAL YEAR 2007

Deutsche Börse AG was to issue one new share ('bonus share') for each existing share following the close of trading on 8 June, 2007. With this measure the company implements a resolution by the Annual General Meeting held on 11 May, which aims to further increase the liquidity of Deutsche Börse's shares. The stock quotation was set to be adjusted before market opening on 11 June, 2007, and will result in the shares being quoted roughly half the price. The new shares carry dividend rights from the beginning of fiscal year 2007.

The AGM resolved a capital increase using retained earnings at a ratio of $1: 1$, by $€ 100$ million to $€ 200$ million, followed by the issue of bonus shares. Since the capital increase has now been entered in the commercial register, the company can issue 100 million bonus shares to its shareholders. These shares will be automatically credited to Deutsche Börse shareholders' securities accounts at their respective custodian banks; no action is required from the shareholders.

DEUTSCHE BÖRSE REDUCES LATENCY TIME AND FURTHER INCREASES NETWORK CAPACITY: DEUTSCHE BÖRSE AND EUNETWORKS CONCLUDE AGREEMENT ON PROVISION OF DARK FIBRE CONNECTIONS

Deutsche Börse Systems has expanded its communications network, which links clients across the globe to the electronic trading, clearing and settlement systems with a new 
connection technology. From the end of May, dark fibre connections are in use between clients and Deutsche Börse access points.

Dark fibre connections are fibre-optic connections used exclusively and offering a virtually unlimited bandwidth that will be made available to Deutsche Börse Systems at a large number of client locations in Frankfurt, London, Paris and Amsterdam by provider euNetworks.

The ever-increasing volume of data in electronic stock exchange trading is prompting higher demands with respect to bandwidth and the minimum possible latency. Deutsche Börse Systems quadrupled the bandwidth of the Eurex and Xetra trading systems in December 2006 and introduced the optional $2 \mathrm{Mbit} / \mathrm{s}$ and 1 Gigabit/s connection types for Xetra in April. Dark fibre will allow such upgrades to be implemented much faster in future.

\section{FIRST UKRAINIAN COMPANY LISTED ON FRANKFURT STOCK EXCHANGE: NEW ISSUE OF TMM REAL ESTATE DEVELOPMENT IN THE OPEN MARKET}

The Frankfurt Stock Exchange saw the listing of

a Ukrainian company for the first time with

TMM Real Estate Development

(US87260H1041). Global Depositary Shares

(GDS) of TMM have been included in exchange trading on the open market. Within the framework of a private placement, the Ukrainian investment bank Concorde Capital placed more than 75 Mio.Euro. Lead broker and designated sponsor is Equinet AG.

According to information provided by TMM, the company is one of the leading Real Estate Development companies in the Ukraine with a focus on High-End Real Estate. TMM was founded in 1992 and has its headquarters in Kiev.
Deutsche Börse remains committed to attracting listings from Central and Eastern Europe on the Frankfurt Stock Exchange. In February the two Russian companies ZAAB AG and IBS Group have been included in the open market of the Frankfurt Stock Exchange.

\section{DEUTSCHE BÖRSE REVIEWS INDEX COMPOSITION - CHANGES EFFECTIVE FROM 18 JUNE}

Deutsche Börse has decided on changes in its equity indices DAX ${ }^{\circledR}$, MDAX $^{\circledR}$ and SDAX ${ }^{\circledR}$ to take effect from 18 June.

Merck will be included in DAX and will replace Altana. The company no longer meets the criteria to remain in the index in terms of market capitalisation and leaves the index on the basis of the so-called fast-exit rule. Altana will move to MDAX replacing Merck. Axel Springer will be included in SDAX, replacing the share of Thiel Logistik. The share of Alstria will also be included in SDAX, replacing the share of Cewe Color.

The next equity index review is scheduled for 5 September, 2007.

\section{CANADIAN VENTURE FUNDS INVEST ADDITIONAL US\$5 MILLION IN HDMI PROVIDER REDMERE}

RedMere Technology Ltd, a leading multimedia networking fabless semiconductor company, today announced the closing of an additional US $\$ 5$ million top up to its first round of venture capital funding, bringing the amount invested in under six months to US\$13.5 million.

The top up round was led by Edgestone Capital Partners, a Canadian private equity firm, along with additional reinvestment by the 
original investors including Celtic House

Venture Partners. RedMere will use the funding to expand its portfolio of unique multimedia communications chipsets, aligned with market expansion in Asia.

RedMere designs and markets chipsets that are used in the fast-growing HDMI devices market, from flat screen televisions to surround sound systems. The advanced communications microchip technology manages the faster flow of complex video and audio data to improve performance and reliability.

The company has produced a range of patented chipsets that were unveiled at the Consumer Electronics Show in Las Vegas in January 2007 and will be launching its expanded portfolio of HDMI products commencing Q2 2007.

According to Instat 2006, there will be 200 million HDMI units in the marketplace by 2008. Many of these are visible in LCD and Plasma televisions but also include Media Centres, Media PCs, Set-top-boxes, Projection Systems, Home Theatre Systems, DVD Recorders and Personal Video Recorders. RedMere's technology enhances the performance of these devices and the subsequent user experience.

RedMere officially opened an office in Taipei, Taiwan and has recently moved its headquarters to new offices in Balbriggan, Co Dublin. Its design office in Cork will be expanding into new premises in Q2. All the design and production management of its unique chipset is handled by an R\&D team of engineers in Dublin and Cork with physical production outsourced to Taiwan.
OXFORD CAPITAL PARTNERS, QNB AND ANSBACHER CREATE QATAR CAPITAL PARTNERS

Oxford Capital Partners, Qatar National Bank (QNB) and Ansbacher have joined forces to create Qatar Capital Partners, a venture capital business focused on developing technology within Qatar. The consortium draws on the core expertise of each of the participants and has successfully bid to act as fund manager for two Qatar Science \& Technology Park (QSTP) venture capital funds.

The joint venture will manage the QSTP New Enterprise Fund and the QSTP Technology Venture Fund. These funds will invest in science and technology companies based within QSTP with the potential for significant growth. The New Enterprise Fund moves technology from the lab bench to the marketplace by supplying the seed and early stage founding capital for new businesses. The Technology Venture Fund invests in growthstage technology companies, helping them to scale-up production and expand their technology pipeline. Both funds are pivotal in establishing Qatar as a Gulf centre for start ups in a range of fields including technology, gas and petrochemicals, healthcare, environmental engineering and new industrial processes. They mark the beginning of Qatar Capital Partners' commitment to this area.

Qatar Capital Partners was authorised by the Qatar Financial Centre Regulatory Authority to establish operations in the Qatar Financial Centre on 29 March, 2007. 